\title{
Enterprise Architecture Implementation Is a Bumpy Ride: A Case Study in the Norwegian Public Sector
}

\author{
Anne Kristin S. Ajer and Dag Håkon Olsen \\ University of Agder, Kristiansand, Norway \\ anne.k.ajer@uia.no \\ dag.h.olsen@uia.no \\ DOI: 10.34190/EJEG.17.2.002
}

\begin{abstract}
Enterprise architecture (EA) is a widespread approach for the development of new digital solutions in a planned and controlled way for large and complex organisations. EA is also viewed as a prerequisite for the digitalisation of the public sector. However, public sector organisations struggle to implement EA programmes, and research has demonstrated that organisational and managerial issues are critical obstacles to EA implementation. This study aims to increase our understanding of EA implementation in the public sector by investigating the central challenges for EA initiatives and to trace the progress of current EA initiatives in the Norwegian public sector. An additional goal is to disclose some ways to improve the situation. We conducted three interpretive case studies in the hospital, higher education, and labour and welfare sectors. We have identified 28 challenges to the EA initiatives. We find that organisational and technical complexities, as well as a limited understanding of EA and lack of formal EA governance mechanisms, are significant obstacles. Among others, the lack of understanding of EA and its methodology will lead to problems with anchoring the EA approach in the organisation and facilitating the necessary EA arrangements to induce the promised benefits of EA, which are necessary requirements to establish the EA initiative's legitimacy and foster the organisation's willingness to implement change. Our study provides four lessons learned for planning and implementing EA initiatives, as follows: \#1. It is advisable to take small steps. \#2. The use of external consultants should be carefully considered. \#3. Formal architectural governance mechanisms are important for legitimacy and enforced use. \#4. Executive commitment and understanding of EA are crucial for achieving a sustainable EA initiative. Finally, we find a common evolution of the EA initiatives through the phases of optimism, resistance, decline and finally, reconsolidation of the most persistent ones.
\end{abstract}

Keywords: enterprise architecture, digital transformation, public sector, e-government

\section{Introduction}

Enterprise architecture (EA) is viewed as an important requirement for success in the digital transformation in the public sector (Hjort-Madsen and Pries-Heje, 2009; Ojo, Janowski and Estevez, 2012) and has become a common approach among European governments (Królikowska, 2011; Bakar and Selamat, 2016). EA is a systematic way to develop and maintain business processes and related information and communications technology (ICT) in a coherent way and in accordance with an organisation's vision and strategy (Jonkers, et al., 2006; Ross, Weill and Robertson, 2006). EA management (EAM) is the discipline used to plan and control the transformation (Aier, Gleichauf and Winter, 2011). The major internal drivers for EA are business-IT alignment and cost reduction, and the major external drivers are legal requirements (Schöenherr, 2008). Despite an increasing interest in EA research in this millennium, EA implementation remains a problematic endeavour (Simon, Fischbach and Schoder, 2013; Dale and Scheepers, 2019). Moreover, it is more problematic in the public sector than in the private sector, but the underlying reasons are not clear (Mezzanotte and Dehlinger, 2014). Over the last decade, EA has been regarded as the instrument for achieving the national goals of ICT coordination and interoperability for the Norwegian public sector (NICT, 2008; Ministry-of-Health-and-CareServices, 2009; Ministry-of-Local-Government-and-Modernisation, 2009). The Norwegian Agency for Public Management and eGovernment (Difi), Difi (2012), states that an EA consists of principles, methods and models, whose purpose is to develop and implement solutions in a holistic and coherent way, with the aim of securing the alignment between work processes and IT, as well as avoiding silos. However, research has documented substantial challenges in obtaining appropriate results from the current EA initiatives in the Norwegian public sector. Ulriksen, Pedersen and Ellingsen (2017) report challenges related to a specific standard for an electronic health record (EHR) system, and Øvrelid, Bygstad and Hanseth (2017) report disputes on how centralised governance for a specific EHR system can impede local innovation. However, these studies position themselves in the information infrastructure literature and do not address the challenges within the EA research stream. Importantly, from the perspective of our research interest Ulriksen, Pedersen and Ellingsen (2017) call for more studies on the complex power dynamics among stakeholders in the process. 
In our literature review, we have found case studies covering EA challenges in several countries (e.g. Janssen and Hjort-Madsen, 2007; Carota, Corradini and Re, 2010; Valtonen, et al., 2011; AlSoufi, 2014; Moreno, et al., 2014; Zadeh, et al., 2014; Bakar and Selamat, 2016). Nevertheless, Dang and Pekkola (2016) call for more research related to problems with EA in the public sector, for example, using case studies from other countries. Moreover, Dang and Pekkola (2017) find that the research in the public sector is immature, and they recommend further studies on implementation and adoption issues. We find these calls appropriate because many of the identified challenges in EA come from studies in the private sector, or in a mix of private and public sectors, and the public sector has institutional constraints that influence inter organisational collaboration in ways other than those in the private sector (Fountain, 2004). Since research on EA methods is well covered, researchers should address establishing architectural thinking (Seppänen, Penttinen and Pulkkinen, 2018). Improving EA governance still requires in-depth knowledge on how EAM is integrated into the organisation, the characteristics of the enterprise architects and the factors that influence the evolution of EAM (Rahimi, Gøtze and Møller, 2017; Rouhani, et al., 2019), as well as the dynamic nature of EA (Schilling, Haki and Aier, 2018). To contribute to the EA literature by addressing the calls for more country-specific studies related to challenges in EA implementation in the public sector and to enrich insights into EAM, we find it useful to more closely address the following questions: How have the EA initiatives in Norway progressed? What are the main challenges encountered by the EA initiatives? To answer these questions and aiming for generalisability, we have conducted an interpretive case study with qualitative interviews and document reviews in three Norwegian public sectors.

We continue this paper as follows: In Section 2, we account for our study's theoretical grounding. Next, we describe the research context and method in Section 3. In Section 4, we present our findings from three case studies. In Section 5, we discuss the findings in light of previous research. Finally, we conclude with a brief summary, suggest some implications for the national authorities and offer recommendations for future work.

\section{Enterprise Architecture and Challenges}

Since the 1990s, EA has been used as an approach in large organisations to manage complex information technology (IT) landscapes in a systematic way (Ross, Weill and Robertson, 2006; Bernard, 2012). There is no common definition of EA (Rahimi, Gøtze and Møller, 2017), but it is usually perceived as the recognition of an organisation's need for ICT solutions from a holistic perspective. A holistic perspective on EA provides the architecture to support the organisation as a whole (Jonkers, et al., 2006; Ross, Weill and Robertson, 2006; Bernard, 2012). EA is viewed as the enabler for making the transition from lower to higher maturity states, for example, this would aid an organisation in progressing from isolated silos to integrated solutions across the organisation, making the IT landscape efficient, robust and flexible (Ross, Weill and Robertson, 2006). The scope of EA has expanded from applying a technical approach, via integrating the business, to including organisational strategy and business development (Rahimi, Gøtze and Møller, 2017).

Based on the definitions of Jonkers, et al. (2006); Ross, Weill and Robertson (2006); Bernard (2012), we synthesise the following definition of EA: EA is a hierarchical description of organisations' current and future states, represented by artefacts describing the business processes and IT components, including information models, hardware and software to support the business processes. EA thus enables the transition towards the organisations' vision in a coherent and systematic way. Consequently, the organisations' capability to be agile and responsive to change is strengthened.

In an effort to arrive at the problematic transition between strategy and implementation of complex systems, Zachman (1987) prepared a framework to improve this conversion. Today, there are several EA frameworks, and one of the most popular is The Open Group Architecture Framework (TOGAF) (Simon, Fischbach and Schoder, 2013; Denert-Stiftungslehrstuhl, 2015). However, the frameworks need adjustment for specific organisations (Buckl, et al., 2009) or can be used as conceptual models for new frameworks, as Armour, Kaisler and Liu (1999) did for the US Department of the Treasury, where they used concepts from three frameworks, namely Zachman's, TOGAF and the Technical Architecture Framework for Information Management (TAFIM). Additionally, there are frameworks for specific industries (Gong and Janssen, 2019), yet some organisations only use parts of a framework (Fallmyr and Bygstad, 2014) or none at all (Denert-Stiftungslehrstuhl, 2015). However, frameworks can be hard to use and understand. For example, in an attempt to solve practical 
problems with the national EA framework for Finland, an alternative concept called Lean EA development was formulated (Hosiaisluoma, et al., 2018).

An EA approach is about how an organisation plans and develops its EA. Kotusev, Singh and Storey (2015) compare three different approaches to EA identified in the literature, as follows: a traditional stepwise approach with strong support from frameworks, the Massachusetts Institute of Technology approach where the vision represented in a core diagram is essential, and a more dynamic 'ad hoc' approach. In short, achieving business strategy alignment with IT is important for all approaches. EAM is a separate discipline and a common term for the processes of planning, executing, controlling and maintaining the organisation's EA (Buckl, et al., 2009; Weiß, 2015).

Governance, management, planning, and communication and support are common success factors (CSFs) in five EA implementation success models (Nikpay, et al., 2013). In a recent study, Rouhani, et al. (2019) not only verify the top CSFs in the literature, governance, management, support (top management commitment) and communication, but also identify two additional CSFs the readiness of technology and infrastructure and EA team capability. Lange, Mendling and Recker (2016) and Löhe and Legner (2014) describe several challenges for EAM; EA requires a lot of effort, which leads to problems with measuring the benefits, and delays are common. The lack of governance, insufficient support for EA development from the business and IT management, as well as inadequate resources and skills, are central issues in their articles. The reason why top management commitment is so critical is summed up as follows: '[...] indeed, without management's commitment, the EA project is doomed to failure' (Banaeianjahromi, 2018a, p.102).

In an effort to explain how to achieve benefits from EA, Shanks, et al. (2018) conceptualise EA service capability, which is formed from four components: EA content, EA standards, EA stakeholder participation and EA skills and knowledge. EA content refers to models describing the business and the IT systems, as well as roadmaps for planning purposes. EA standards comprise policies, rules and guidelines that direct architects in designing and managers in controlling the EA. EA stakeholder participation involves stakeholders other than the EA team, including management, relevant business and IT personnel who are crucial in establishing the foundations for the EA service capability. Finally, EA skills and knowledge pertain to EA professionals' need to acquire extensive knowledge of an organisation's business and IT, in addition to being communitive.

Notwithstanding the knowledge about CSFs and well-developed EA frameworks, empirical studies in the public sector worldwide demonstrate challenging implementation issues for EA. A recurring problem pertains to organisational issues, such as inadequate support, involvement and understanding from management and business units (Hjort-Madsen and Pries-Heje, 2009; Banaeianjahromi and Smolander, 2016; Dang and Pekkola, 2016; Banaeianjahromi, 2018a; Seppänen, Penttinen and Pulkkinen, 2018). Furthermore, socio-technical issues related to the many different actors involved from different autonomous organisational units pose problems with authority, prioritising of projects and agreement on standards (Boh and Yellin, 2006; Hjort-Madsen, 2006; Saarelainen and Hotti, 2011; Drews and Schirmer, 2014; Bakar and Selamat, 2016; Dang and Pekkola, 2016).

Another theme is EA governance and management, where the lack of guidelines and appropriate frameworks causes challenges (AlSoufi, 2014; Drews and Schirmer, 2014; Bakar and Selamat, 2016; Hosiaisluoma, et al., 2018). Likewise, insufficient tool support is problematic (e.g. the absence of shared repository and inadequate modelling tools for inter-organizational settings) (AlSoufi, 2014; Drews and Schirmer, 2014; Bakar and Selamat, 2016; Banaeianjahromi and Smolander, 2016). The last recurring theme that we pinpoint is the need for stable and knowledgeable EA and IT personnel (Bakar and Selamat, 2016; Banaeianjahromi and Smolander, 2016; Dang and Pekkola, 2016; Seppänen, Penttinen and Pulkkinen, 2018).

\section{Research Setting and Method}

\subsection{Research Setting}

In its effort to coordinate ICT investments, the Norwegian government, through the Ministry of Local Government and Modernisation (LGM), has developed principles for ICT architecture. Difi has subsequently described these as EA principles (Ministry-of-Local-Government-and-Modernisation, 2009; Difi, 2012). A directive from LGM states, 'To contribute to a coherent whole in public ICT-solutions and services, governmental enterprises shall follow common architectural principles [...] elaborated by Difi (Ministry-ofLocal-Government-and-Modernisation, 2011). The sectors that we have studied are the hospital sector, the 
higher education sector (HES) and the Norwegian Labour and Welfare Administration (with the acronym NAV in Norwegian).

\subsection{The hospital sector}

Norwegian hospitals are organised into four independent enterprises, called regional health authorities (RHAs). This case focuses on South Eastern RHA (SERHA), which serves the country's largest region, with 10 health trusts (HTs) and 78,000 employees. In addition to a department for technology and eHealth, SERHA has organised its ICT operations as a trust, called Hospital Partner (HP).

The RHAs are owned by the Ministry of Health and Care Services (HCS). Each RHA exercises some authority over the HTs in its region; this is regulated by laws. For example, the RHA can influence and to a certain degree decide on what ISs the HTs shall use. Investments in ICT are made at both the regional and the trust levels. The National ICT (NICT) was established at the initiative of the HCS in 2003; in 2014, the NICT was reorganised as a separate trust owned by the four RHAs. The NICT's main work areas are strategic coordination, prioritisation and consolidation of a common approach to key ICT issues across the regions. One of the goals is to establish an EA strategy.

At SERHA, all the HTs have their own ICT portfolios, and SERHA has an ongoing portfolio programme called Digital Renewal to develop shared regional solutions for important areas in clinical and administrative settings and research. The budget allocation for Digital Renewal for $2013-2020$ is 6585 MNOK, and the accumulated expenses in 2017 amounted to 4521 MNOK. One of the programmes is named Regional Clinical Solution (RCS); some of its large projects are consolidating its electronic patient journal system and implementing regional solutions for laboratory, radiology and multimedia.

\subsection{The higher education sector}

The second case involves the HES, which is under the authority of the Ministry of Education and Research. We have studied universities and university colleges (UUCs) and their challenges in establishing an EA practice. Of the 33 independent higher education institutions, 9 are fully accredited universities, and 24 are public institutions. There are some organizational units that work across the sector, e.g. the Joint Study Administrative Service Center.

The individual institutions and their systems have developed relatively independently, and the systems are usually different and have not always been designed to interface with one another. This situation makes cooperation among these entities difficult and expensive. There has been some progress with a few administrative systems, which are now operated as common resources. Pending the establishment of a formal council, an informal architectural council has elaborated on architectural principles for the sector.

\subsection{The Norwegian Labour and Welfare Administration}

The NAV is the third case, which involves yet another ministry, the Ministry of Labour and Social Affairs. The NAV was created in 2006 through a fusion of state agencies and municipal organisations for social services administration to make it more efficient, holistic and client friendly. The NAV employs around 19,000 people.

The organisation consists of seven departments, of which three comprise different business lines, and four are support departments, one being the ICT department. The NAV's services are innovated and developed in programmes and projects. The NAV has established an EA section to align the programmes and the projects with the NAV's long-term goals. NAV (2016), prepared by a group with members from the departments, describes the NAV's EA approach, explaining why EA is important, as well as the NAV's roles and responsibilities.

\subsection{Research Approach, Data Collection and Analysis}

We used a qualitative and interpretive research approach in these exploratory case studies (Walsham, 1995). In our initial studies from 2015 to 2017, we examined the use of EA and the general challenges related to the national EA initiative. The first case involved the HES sector, selected due to the easy access at our local university. However, due to the HES sector's limited use of and experiences with EA, we continued to investigate other sectors with more experience and with different organisational structures. From the interviews conducted in the hospital sector in 2017, we wanted to gain a comprehensive understanding of the 
challenges disclosed in the first studies and to gain insights from the use of EA during the last two years, in line with the hermeneutic approach (Klein and Myers, 1999). We held subsequent interviews in 2018 and 2019 to obtain information about the initiatives' status and progress.

The principles from Klein and Myers (1999) work were used to gain an in-depth understanding of the phenomena. The main data collection method consisted of semi-structured interviews; for some of the cases, the questions were revised after new insights emerged. Table 1 provides an overview of the interviewees. The units in the table refer to jurisdictional organisations, except for NAV, whose units are departments. The interviewees were selected by contacting key persons in the ICT departments or identified as enterprise architects at LinkedIn, followed by the snowballing technique where the interviewees recommended other relevant persons. All interviews were recorded and transcribed, except for one where the informant disapproved of the recording. The interviews included topics on the need for EA; the status of the EA work; how the EA work was organised; practices, competency, involvement of different stakeholders; and what the interviewees perceived as the main challenges to the EA initiative. Documents from each sector and documents related to the national architecture were collected from the organisations' websites.

Table 1: Overview of cases and interviews

\begin{tabular}{|c|c|c|c|c|c|}
\hline $\begin{array}{l}\text { Case and } \\
\text { number of } \\
\text { units } \\
\text { investigated }\end{array}$ & $\begin{array}{l}\text { Year of } \\
\text { inter- } \\
\text { view }\end{array}$ & $\begin{array}{l}\text { Number } \\
\text { of } \\
\text { inter- } \\
\text { views }\end{array}$ & Types of informants & $\begin{array}{l}\text { Average } \\
\text { length of } \\
\text { interviews } \\
\text { in minutes }\end{array}$ & $\begin{array}{l}\text { Interview } \\
\text { method }\end{array}$ \\
\hline $\begin{array}{l}\text { UUC } \\
9\end{array}$ & 2015 & 11 & $\begin{array}{l}5 \text { ClOs, } 2 \text { enterprise architects, } 2 \text { chief } \\
\text { engineers, } 2 \text { group managers. } \\
\text { The interviewees are from } 5 \text { universities, } 3 \\
\text { university colleges, and } 1 \text { from the Joint Study } \\
\text { Administrative Service Centre. }\end{array}$ & 40 & $\begin{array}{l}10 \text { telephone } \\
1 \text { face-to-face }\end{array}$ \\
\hline $\begin{array}{l}\text { hospital\#1 } \\
2\end{array}$ & 2015 & 12 & $\begin{array}{l}9 \text { enterprise architects and } 3 \text { group managers. } \\
\text { The interviewees are from SERHA and HP. }\end{array}$ & 40 & Telephone \\
\hline $\begin{array}{l}\text { NAV } \\
4\end{array}$ & 2017 & 16 & $\begin{array}{l}4 \text { directors, } 7 \text { enterprise architects, } 1 \text { project } \\
\text { manager, } 4 \text { section managers. } \\
\text { The interviewees are from } 3 \text { business lines } \\
\text { and the ICT department. }\end{array}$ & 45 & Face-to-face \\
\hline $\begin{array}{l}\text { hospital\#2 } \\
5 \\
\text { (3 additional } \\
\text { units) }\end{array}$ & 2017 & 16 & $\begin{array}{l}1 \mathrm{CEO} \text { and } 1 \mathrm{CIO} \text { from a } \mathrm{HT} ; 10 \text { enterprise } \\
\text { architects from NICT, SERHA, HP, and } 2 \mathrm{HTS} \text {; } \\
\text { and } 3 \text { project managers from SERHA and HP. }\end{array}$ & 70 & $\begin{array}{l}3 \text { telephone } \\
1 \text { video } \\
12 \text { face-to- } \\
\text { face }\end{array}$ \\
\hline hospital & $2018-2019$ & 15 & $\begin{array}{l}5 \text { enterprise architects, } 3 \text { project managers, } 4 \\
\text { directors, and } 3 \text { managers. } \\
\text { The interviewees are from SERHA and HP. }\end{array}$ & 60 & $\begin{array}{l}11 \text { telephone } \\
2 \text { video } \\
2 \text { face-to-face }\end{array}$ \\
\hline UUC & 2019 & 2 & $1 \mathrm{CIO}$, and $1 \mathrm{CEO}$ from one university. & 15 & Telephone \\
\hline NAV & 2019 & 1 & $1 \mathrm{ClO}$ & 20 & Telephone \\
\hline
\end{tabular}

The acronyms in Table 1 are: UUC = university and university colleges, NAV = Norwegian Labour and Welfare Administration, NICT = National ICT, SERHA = South Eastern Regional Health Authorities, HT = health trust, HP is Hospital Partner $\mathrm{HT}, \mathrm{ClO}=$ chief information officer, and $\mathrm{CEO}=$ chief executive officer.

To analyse the challenges, the specialised tool for qualitative analysis, NVivo, was used in all cases. The transcripts from UUC and hospital\#1 were analysed stepwise (Oates, 2006), with no predefined categories. The transcripts from NAV were assigned to categories taken from the studies of Banaeianjahromi and Smolander (2016) and Lucke, Krell and Lechner (2010). The second author was in charge of these three cases, while the transcripts from hospital\#2 were coded and analysed by the first author, following the principles of first- and 
second-cycle coding (Miles, Huberman and Saldaña, 2014). The themes were created on the fly. In the second cycle for hospital\#2, the data were aggregated, discussed, organised and compared in an interpretive and iterative process to identify emerging themes and patterns. In the first iteration of the second cycle, all EA challenges were combined in one group and coded into 30 concepts. In the second iteration, the concepts were reassessed and grouped into broader categories. This analysis ended up with five main categories and 26 challenges. The analysis continued in Excel, with mapping of the challenges from the other cases into the schema from hospital\#2. Due to different coding and analysing approaches, we first reviewed the challenges found in the first three cases and aligned them with the challenges found in hospital\#2, so we could compare the data. Surprisingly, we discovered only a few new problems. Competition among UUCs, as a hindrance to their commitment to EA, was a new issue. . Further analysis revealed the major challenges which are discussed by (Ajer and Olsen, 2018).

Further discussions led us to the questions of the nature of the challenges, the causes of the challenges, their effects on the EA process, and the party responsible for addressing the challenges. To examine the challenges in the scope of the progress of the EA initiatives from 'as is' until 'to be', we rearranged the challenges from the first analysis and ended up with seven categories and 28 challenges, as presented in section 4.2. At the same time, we drew a timeline for SERHA and discussed the similarities in the factors that had changed the direction of and attention to the EA initiative that we had observed at UUC and NAV. It was possible to obtain these findings due to the rich data we had collected from all cases, including the subsequent interviews in 2018 and 2019. For this analysis, we used Excel and compared the data related to the themes that emerged throughout the discussions, which comprised top management support, anchoring in the organisation, governance mechanisms, understanding of EA, and certain events that had an impact on the progress. The results of this analysis are presented in section 4.1.

In the discussion section, we provide four lessons learned which the analysis process, and in particular leaning on the discussions with key stakeholders, led us to select as the most significant ones. We conjectured that these lessons are related to solving the fundamental challenges.

\section{Findings}

First, we present the progress of the EA initiatives as they unfolded in the HES, the NAV and SERHA. Second, we cover the reported experienced challenges from the process.

\subsection{Progress of EA Initiatives}

When EA was introduced in the three sectors, it was perceived as an appropriate methodology to solve urgent organisational needs in order to realise the political visions related to the use of ICT (Ministry-of-LocalGovernment-and-Modernisation, 2009). All of the sectors became interested in exploring EA and started to build their EA service capability. This was done by educating their personnel in the EA framework, creating stakeholder awareness and starting to adapt and create guidelines and rules for EA practice. However, when they started the implementation by building the transition maps from 'as is' to 'to be' and equipping the organisations with the necessary mechanisms to accomplish the mission, they met a 'wall of complexity'. This undermined the EA initiatives and put them more or less on hold in all three cases. The lack of top executive commitment, of involvement from others besides the IT department and of formalisation were important causes of the problems in the first phase of the EA initiatives. From the UUC, the following quote from an informant show the situation in this early phase: 'These [architectural principles] are drawn from IT, and it is mainly the IT directors who are connected and give the assignments. This must also be anchored in the sector and in the management, and a comprehensive commitment to defining processes is still lacking'. Commitment was an issue at the NAV as well; an architect attributes this to the lack of ownership, resulting in projects being 'largely controlled by external consultants because the architecture topic was not hot in the usual operational context'. Moreover, an architect noted, '[...] the enterprise architecture initiatives have died out because they did not get the necessary impact'. At SERHA, we observed that top management commitment was key to the initiative's sustainability, as illustrated by the following quotes from two enterprise architects: 'A strategic leader and the chief enterprise architect together with some enterprise architects took the initiative to use EA [in SERHA]. [...] The responsible director confirmed several times [the] interest [in] building up EA in the organisation. Many initiatives were taken, both regional and national. [...] EA in the RHA vanished when the director and the chief architect quit', and '[...] the leaders simply did not understand it; they thought it was difficult, and it became very theoretical. [...] The new $\mathrm{ClO}$ was pragmatic and wanted action'. 
After a period of limited EA activity in SERHA, it was offered a new opportunity, with the reorganisation of RCS, to improve coordination among the projects. An enterprise architect noted, '[In the RCS programme], the managers of the HP and SERHA and the programme management [...], agreed that we had to establish two architectural functions. One was architecture and design as an operational function in the RCS programme, and [the other was] an architectural board as an interdisciplinary body that could make architectural choices'. These changes became operative in 2015. The challenges experienced in the next two and a half years are embedded in the next section.

We observed that in all cases, architectural thinking and coordination would become more entrenched among the top management over time. This seemed to occur for several reasons, through crises in the organisations' ICT governance, from a strong push by the various ministries or from experiencing that EA would eventually yield significant value. In the HES, the Ministry of Education and Research initiated a new attempt to coordinate the sector, and some goals have now been achieved. In 2018, a new directorate was formed, the Norwegian Directorate for ICT and joint services in higher education and research. This directorate has been in charge of developing a plan to realise the goals in the digitalisation strategy for the UUC. A digitalisation council, with members drawn from the executive leaders of the various institutions, was established. This led to a firm commitment among the institutions and a strong renewed momentum in the EA efforts. In the spring of 2019, a chief information officer (CIO) at a university stated, 'There have been large changes [over] the two last years. The ministry has set the premises. Coordination at the administrative level has been operationalised, but in research and education, there is much work left'.

The NAV also had new initiatives, due largely to external pressure. An architect commented, 'We have had pressure from the outside. We had some attempts [in the organisation] earlier [...]. In connection with our modernisation, [...] we must establish a good enterprise architecture function. It has been a prerequisite for getting money to modernise our IT systems'. However, they still struggled with organisational acceptance and understanding among the top managers. A director stated, 'The initiative is well anchored. That being said, not everyone in the top management understands what they have been involved in. So even if it is thoroughly anchored, I would say that ownership is definitely a bit varying'.

Since 2015, SERHA has gained useful experiences with EA practices and has adapted the methodology accordingly. As assessed by an enterprise architect, 'Through the programme Regional Clinical Solutions, we have established a methodology, with templates, that is well connected with other issues, like project portfolio management, benefits realisation and change management. [...] We are now assessing how we can lift the architectural board from RCS to a regional level'. In our latest interviews at SERHA in December 2018, we encountered both negative and positive experiences regarding the EA practices, but the sentiments were mainly positive. After some crises in parts of the Digital Renewal portfolio programme in 2017 and 2018, we found that architectural thinking had moved high up on the agenda among the top managers. A director commented, 'We agreed that one had to get better control of the architecture in HP. Since the beginning of 2018, we have been working on this, and the idea is that this will also be balanced with the regional architecture governance'.

From our findings, we have conjectured that the EA initiatives proceeds in four phases: optimism, resistance, decline and reconsolidation. This model is discussed in section 5.

\subsection{Challenges in the EA Process}

Figure 1 shows the seven categories with 28 associated challenges that we identified. The figure illustrates that in the 'as is' situation, there are challenges caused by historical organisational structures and technical conditions, as well as challenges related to technical innovation and political initiatives. These structures provide inputs to the EA process, whose intention is to develop the 'to be' situation. The process has met many challenges, among others, from the nature of $E A$ itself, with large projects and a long time horizon. We have decided that organisational issues constitute a specific category of challenges that is related to the EA initiatives, although willingness to change and strategic choices are challenges in change management in general. Since competency has challenges in many important facets, we have classified it as a separate category, although it could be argued that it is also an organisational issue. We suggest that the two categories organizational issues and competency are mainly the top managers' responsibility. In the category $E A$ 
execution process, we have sorted the challenges related to the enterprise architects' work for which the architects themselves have the main responsibility, likewise for the challenges related to EA technical issues.

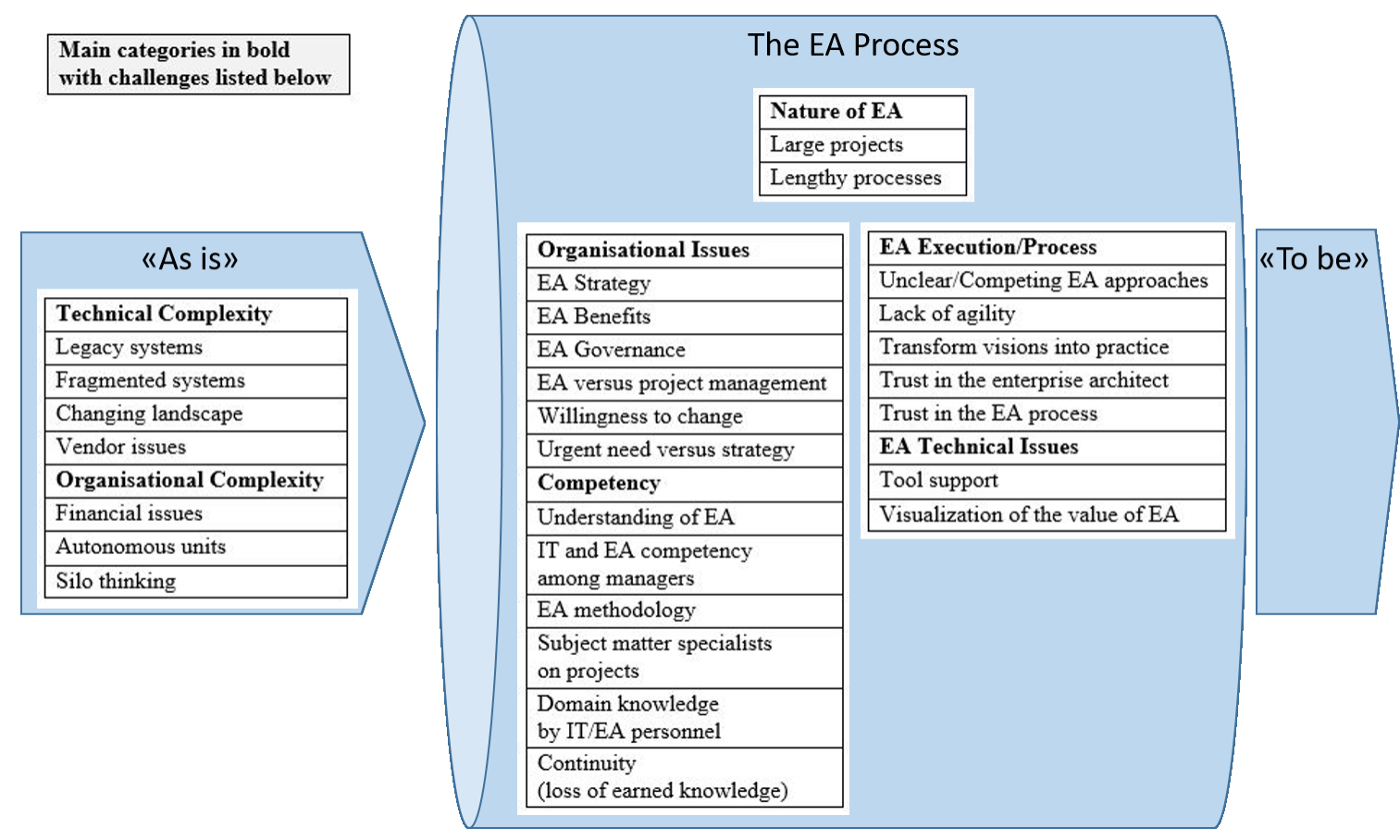

Figure 1: Challenges in EA implementation.

Due to this paper's space limitations, we describe only the challenges from the categories of technical complexity, organisational complexity and competency, as well as selected challenges from organisational issues. However, all categories received full attention in our analysis. The interviewees frequently mention the first two categories, which we find to be the major challenges leading to 'the wall of complexity' (see section 4.1). The other selected challenges mirror the lack of top managers' support or are underlying causes of such lack, which impede the EA initiative. However, when some of these challenges are addressed, the conditions for the EA initiatives improve. These challenges are therefore connected to the research question of how the EA initiatives have progressed.

\subsubsection{Technical complexity}

In the technical complexity category, we identified four challenges that caused the complexity in the IT landscape. First, the fact that there were prior large investments in legacy systems designed for the business lines was pinpointed in all cases. Such systems were not designed for integration, and some vendors were not very collaborative in facilitating integration. Second, fragmented systems had developed over time in SERHA and the UUC. Different systems and systems customised in different directions created challenges for integration and standardisation. Third, the changing landscape was an important issue in SERHA and the NAV, where new systems, changes in functionality and changes due to political decisions occurred frequently. Fourth, long-term contracts with vendors influenced the speed of changing and renewing the ICT portfolio in SERHA.

\subsubsection{Organisational complexity}

Financial issues and organisational autonomy were particularly important in all three cases. First, we identified several financial issues related to EA initiatives. Three of these issues were particularly prominent: 1) Whose budget would be involved, and who would receive the benefits? 2) The ICT project cost would be difficult to predict due to the complexity. 3) There were prior large investments in legacy systems. The following statement from a section manager in the NAV is illustrative: '[Legacy systems] make it difficult to manage these systems across departments because the money follows the department'. This view was corroborated by a chief executive officer (CEO) of an HT, who commented, '[...] we should have been committed to working systematically, guided by standardised processes that realise benefits, [...] and we should be measured on this. The central authority [HCS] needs to rearrange the way the cost is distributed since it is very demanding to 
take money from the daily operations related to the treatment of the patients when the cost rises and is unpredictable'. An enterprise architect in SERHA noted, 'Portfolio management wants a complete programme and project budget allocated for the whole delivery lifecycle'. Another enterprise architect complained about this situation and said, '[...] we don't know everything up front, so it is hard to estimate the costs'.

Second, in all three cases, autonomous units exercised control over their own decisions and how they organised themselves, and they had their own budgets. This autonomy hampered the initiative for increased cooperation. For example, even if an HT was owned by an RHA, the HT would not be legally committed to following the RHA's recommendations. Under certain conditions, an HT could also refuse to use a new IS or to set aside resources for developing an IS. Several of the informants from the UUC noted the disagreement between the Ministry of Education and Research and the institutions about which entity should be assigned the responsibility for the EA work and how the costs should be allocated.

A project manager in SERHA explained, 'Each HT is an autonomous unit, so it is difficult if some do not want to participate-there are few incentives'. An enterprise architect clarified the relationship between the NICT and the RHAs: 'NICT, in general, cannot require an RHA to do certain things, but recommendations from the Board of $\mathrm{NICT}$, where the $\mathrm{CIO}$ from the regions attend, will be followed up [...]'. Nevertheless, another enterprise architect noted that the recommendations from the NICT were not always taken into account. 'It is a possibility that the governance model and economic incentives are not adjusted to the goals'.

The departments worked independently in the NAV, without much interaction. An enterprise architect noted, 'NAV is a strong line-driven organisation, [with] very little matrix focus. A [horizontal perspective] has very little authority and power in practice, and the hierarchy in government organisations reinforces this'. This statement is corroborated by the following quote from a section manager: 'When it comes to architectural governance, you move in different structures than you do in the line structure. So sometimes, the management structures are a bit incompatible'.

The architectural principles that had been proposed for the UUCS were only advisory in nature. One of the informants stated, 'Now it is based on a voluntary principle if one views the sector in its entirety'. One of the causes of this lack of collaboration was the competition among the UUC units to increase their student enrolment and obtain research funding.

Additionally, silo thinking was a significant issue in SERHA and the NAV. Decision makers felt comfortable with the way that things worked in their silos and did not see the need to contribute to common coordination, and thus, they did not see the need for EA.

\subsubsection{Competency}

The understanding of EA was particularly important in all cases. We found that people working with IT management had an adequate understanding of EA, but there was less understanding among the other stakeholders. The following statement from an enterprise architect in NICT is illustrative: 'NICT consists of people with good knowledge of EA; [...] out in the RHAs and in the HTs, people think of EA more like technical IT architecture than how to design and build an organisation'. Another enterprise architect from the HP asserted, '[...] outside the circle of architects in the eHealth directorate, NICT and SERHA, EA is not very well understood, and top managers in SERHA do not [...] understand the value of EA'. An enterprise architect in SERHA alleged, '[It is important to] convince the enterprise leaders that there is a need to involve architecture as a discipline when assessing the changes [that] one should invest in'. The consequences of the limited understanding of EA were that the enterprise architects were introduced too late in the projects and not involved in high-level planning.. One informant from the UUC noted that even if enterprise architects were involved, project managers could choose not to investigate whether work processes should be changed. The informant added, 'And then you lose some of the intentions behind EA'. Furthermore, the lack of general IT knowledge among managers was experienced as problematic, likewise with the insufficient knowledge of $E A$ methodology and the limited understanding of the enterprise architect role.

It was a significant problem to obtain the 'right' resources and staff the project team with people who had authority and legitimacy, but again, this was intertwined with the other categories. Domain knowledge among IT personnel and enterprise architects was also an issue, and it was associated with a continuity problem. In SERHA, maintaining the knowledge about the projects was perceived as a challenge due to insufficient 
documentation, people being transferred to other projects or people quitting. In SERHA, they used resources from the HP in the RCS programme, and approximately 50\% of the architects were external consultants; this practice was disputed since they then invested in the core competencies of people who worked there on a short-term basis. Nevertheless, a manager in SERHA stated, 'external consultants can be a boost in the beginning, related to the use of EA methodology'. In the NAV, external EA consultants had made plans that were not aligned with the NAV business. However, an architect from the NAV explained that the management had realised that 'we need our own employees to be the ones who ensure continuity and for example, ensure proper documentation'.

\subsubsection{Organisational issues}

We highlight some of the major challenges in this category. EA governance is about structures supporting a decision setup with mechanisms for sufficient impacts on the process, such as authoritative architectural boards, formal guidelines, how they are organised (e.g., staffing projects) and their effect on the relationship between EA and project management. In the UUC, we discovered a disagreement on where the responsibility for architecture should be placed, and in the spring of 2015, no architectural board had been established. In SERHA and the NAV, the misalignment between EA and project management, meaning that the project managers' use of architectural methodology was optional, had negative implications for the progress of the EA initiatives. However, by mid-2017, architecture had become a distinctive point in the project methodology for SERHA.

\section{Discussion}

EA is viewed as a prerequisite to the digitalisation of the public sector, but it turns out to be very challenging to manage the EA projects in practice (Bernus, et al., 2016; Dang and Pekkola, 2016; Banaeianjahromi, $2018 \mathrm{~b}$ ). Our findings from three different public sectors in Norway demonstrate the multifarious challenges in implementing EA. In this section, we first argue for a common pattern for the evolution of the EA initiatives in the three cases. We then discuss major challenges to the EA initiative, and present four lessons learned.

In all the three cases, we witness the same story unfold regarding the progress of the EA initiatives. First, there is a strategic move to adopt EA as a means for the digital transformation of the sectors, in line with national recommendations and similar to other European countries (Królikowska, 2011). Second, the introduction of the EA approach meets organisational resistance, rooted in organisational and technical complexities (Banaeianjahromi and Smolander, 2016; Dang and Pekkola, 2016), e.g. hindering local innovation (Bygstad, 2017). When the concept is additionally difficult to grasp (Seppänen, Penttinen and Pulkkinen, 2018), and it is challenging to demonstrate immediate benefits (Gong and Janssen, 2019), the initiatives lose momentum and top management commitment, with the subsequent withdrawal of support (Venkatesh, et al., 2007). There are many examples of leaders initially backing strategic EA initiatives, only to withdraw their support when there is no immediate return on investment (Venkatesh, et al., 2007). Third, when the EA approach encounters struggles, it can gain new momentum if the top management is sufficiently pressured by external stakeholders, such as the Ministry, to improve the current situation and facilitate the necessary arrangements to make the initiative flourish (Janssen and Kuk, 2006; Venkatesh, et al., 2007; Bui, 2015; Bakar and Selamat, 2016). We suggest that encompassing an initiative such as EA, which involves major upheavals for an organisation, may progress through the phases of optimism, resistance, decline and finally, reconsolidation for the most persistent ones. The organisations eventually realise that the absence of EA is not an option, and thus, they muster executive commitment and determination. We propose that the pattern we have observed is what other organisations can anticipate when embarking on an EA journey if they lack a firm mandate from the start. We find that this EA progress is similar to the Gartner Hype Cycle for emerging technologies (see Figure 2). 


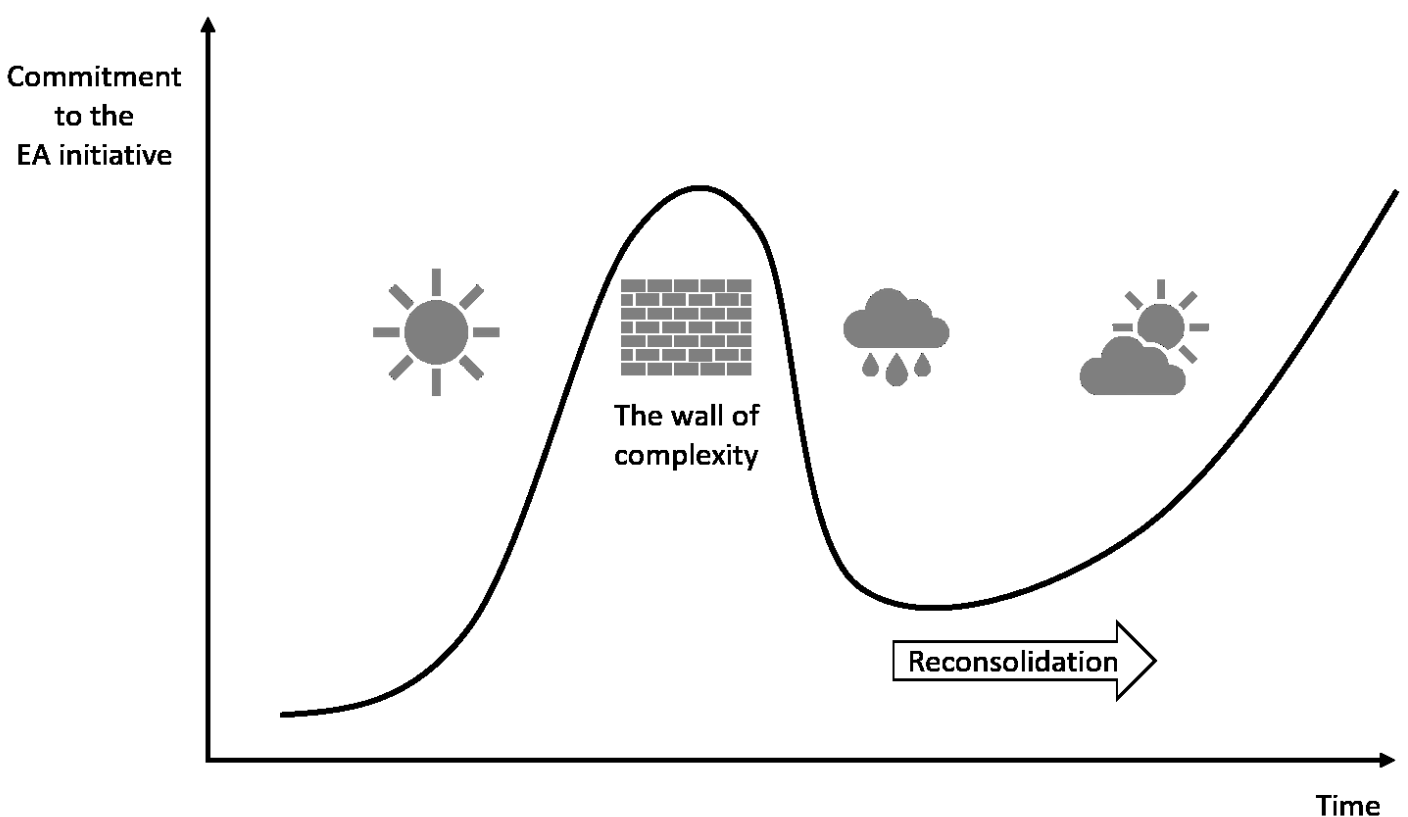

Figure 2: The EA process cycle

We witnessed that organisational and technical complexities, together with competency and governance mechanisms were significant barriers that derailed the EA efforts. The organisational complexity shaped by autonomous units, financial issues and silo thinking, leading to coordination and collaboration challenges.

Coordination and collaboration challenges related to EA initiatives across sub-organisations are well-known phenomena in the public sector (Ross, Weill and Robertson, 2006; Janssen and Hjort-Madsen, 2007; Dang and Pekkola, 2016; Banaeianjahromi and Hekkala, 2019). The situation becomes tougher the more autonomous the sub-organisations are (Boh and Yellin, 2006); hence, it is important to address autonomy to maintain coherence in an organisation (Zadeh, et al., 2014). The consequence of autonomy is that a sector's units can make decisions that complicate coordination (Dang and Pekkola, 2016), and ultimately, the business lines have the strongest voice (Martin, 2012; Bakar and Selamat, 2016).

The complex organisational structures lead to challenges in EA planning (Dang and Pekkola, 2016). EA planning is imperative to achieve the goals outlined in an organisation's strategy (Schmidt and Buxmann, 2011; Jusuf and Kurnia, 2017). Even if the target is clear, the units can disagree about the outlined process (Currie and Guah, 2007). Additionally, UUCs are competitors on student recruitment and funding; thus, there can be forces working against conformity, which also can happen when the EA project set jobs at risk (Banaeianjahromi, 2018b). An EA project opens up an organisation to others, which is perceived as risky by leaders (Valtonen, et al., 2011). Moreover, from a financial perspective, the organisational measurements are not aligned with the EA initiative. The classical problem, where the cost is covered by another unit, not the ones that gain the benefits (Flak, Nielsen and Henriksen, 2012), is also valid for EA projects (Drews and Schirmer, 2014). HjortMadsen and Burkard (2006) conclude that the lack of economic incentives is one of the reasons for interoperability challenges in the government, and Banaeianjahromi (2018b) found limited budget provision to cause delays for EA projects.

Since the enterprise architects also have problems with visualising the benefits, the decision makers are not convinced to participate in change projects applying a new methodology (Chakravarti and Varma, 2008). If a value is not demonstrated from the EA initiative, its dismissal is understandable since changing work processes is a challenging organisational operation, related to both budget allocation and organisational resistance (Chakravarti and Varma, 2008; Drews and Schirmer, 2014). Even if the top management agrees on the EA target, the organisation may be unwilling to free up its key personnel to work on national or regional EA projects (Ulriksen, Pedersen and Ellingsen, 2017). Taking key personnel out of the daily operations makes the unit suffer in terms of both productivity and revenue. Additionally, the willingness to use and participate in EA initiatives is impeded if there are conflicts related to benefits (Van Der Raadt, Schouten and Van Vliet, 2008; Dang and Pekkola, 2016). Moreover, the uncertainty about when the EA benefits will be realised (Schmidt and 
Buxmann, 2011) may sway top managers to prioritise short-term needs instead (Bygstad, 2017). Altogether, there are several sources for top managers to use their power of autonomy and not commit to the EA initiative. In line with prior research that suggests an incremental approach as appropriate in developing EA (Kaushik and Raman, 2015; Rolland, Ghinea and Grønli, 2015; Jusuf and Kurnia, 2017), we propose lesson learned \#1: It is advisable to take small steps; 'eat the elephant in small pieces'. This exerts less pressure on the organisations' resources, leads to useful results along the way and provides better opportunities for agility and innovation, and builds trust to the EA approach.

We found the lack of understanding of the EA concept as one of the major challenges to gaining the momentum and the necessary support for the EA initiatives, this is consistent with findings from (Banaeianjahromi, 2018a). In all three cases, the need for EA was not sufficiently understood by the management, which is crucial 'in order for organisations to justify investment in EA programs and benefit from its value' (Bernus, et al., 2016, p.97). The management has the possibility to make organisations capable of using a new methodology, and building internal competency is important in this sense (Rouhani, et al., 2019).

Forming an EA team is one of the imperative tasks for building an organisation's EA service capability and achieving benefits from EA at a later stage (Shanks, et al., 2018). The extensive use of external consultants in the NAV and SERHA undermined the organisational learning that was needed to build the capability. The use of external consultants makes it challenging to develop knowledge for both the specific professional domains and the different architectural domains. The situation demands the project organisation's strong focus on maintaining the skills of their personnel and undertaking review processes to ensure project conformance to EA plans and principles. The problems, continuity and compliance with the rules related to the use of external consultants have not been explicitly addressed by other researchers, but have been found to be ineffective, inflexible and scarcely helpful in creating innovation (Banaeianjahromi, 2018a). However, it can be beneficial to bring in external consultants (Ross, Weill and Robertson, 2006; Niemi and Pekkola, 2013). EA professionals need a comprehensive understanding of an organisation's business (Niemi and Pekkola, 2013; Shanks, et al., 2018); we conjecture that this is primarily an issue related to internal employees. This leads us to lesson learned \#2: The use of external consultants should be carefully considered.

Anchoring the EA initiative is problematic in the cases. The three sectors' management and staff indicated awareness and acceptance of the concept, but we argue that the challenges in facilitating the necessary governance structures are evidence of poor understanding of EA among the top management, since this is an imperative task for them (Lee, Oh and Nam, 2016). This finding is consistent with that of a Finnish public agency: 'The executive group has understood that EA is an important concept. Unfortunately, it seems that they do not understand the meaning and purpose of it' (Saarelainen and Hotti, 2011, p.15). The importance of governance, with formal structures and boards, is a CSF in all five success models reviewed by Nikpay, et al. (2013), and a significant factor for EA performance in the public sector (Lee, Oh and Nam, 2016). Furthermore, a governance structure is 'required to manage EA consistently even without permanent top management attention' (Winter and Schelp, 2008, p.551), and the lack of such a structure makes it challenging to govern the EA (Banaeianjahromi, 2018b). The unclear setup of EA governance is identified as a possible reason for the failure of EA implementation in Denmark and the Netherlands (Janssen and Hjort-Madsen, 2007) and is found to be a key issue in two Finnish government agencies (Seppänen, Heikkilä and Liimatainen, 2009). This leads us to lesson learned \#3: Formal architectural governance mechanisms are important for legitimacy and enforced use. An architectural board is one such mechanism; principles, guidelines, clear roles and formal authority are others.

Altogether, the data shows that executive commitment and resolution are imperative to keep the EA efforts on track, which many forces threaten to derail. Executive understanding of architectural thinking is a prerequisite for the sustainability of the EA efforts. The creation of new organisational structures that support an EA initiative can only be decided and managed at the executive level. This leads us to lesson learned \#4: Executive commitment and understanding of EA are crucial for achieving a sustainable EA initiative.

We have studied EA implementation in three Norwegian public sectors, which together account for a major proportion of the public sector as a whole. Not accounting for the public sector as a whole is a limitation of our study since we have not investigated other significant segments of the public sector, most notably municipalities, primary healthcare and primary education. Further research should address these contexts and would yield a more complete understanding of the EA implementation issues and challenges in e-government. 
Despite the limitations in the generalisability of the findings, these should serve to enlighten government enterprises about the challenges related to EA implementation.

\section{Conclusion}

In this study, we have analysed how EA initiatives in the Norwegian public sector have progressed and the main challenges to the initiatives. We find that the EA initiatives have progressed through the phases of optimism, resistance, decline and finally, reconsolidation of the most persistent ones. Regarding the main challenges encountered by the EA initiatives, we have identified seven categories with 28 associated challenges. We find that organisational and technical complexities are significant obstacles to EA initiatives; the autonomy of the organisations and the lack of an appropriate financial model are especially challenging. The other major challenges are the lack of understanding of EA and the absence of formal EA governance mechanisms.

Our study contributes to the EA literature in four ways. First, its rich description, based on empirical data, shows that the public sector has the same problems related to EAM organisational anchoring as Lange, Mendling and Recker (2016) find in the private sector; mirrored by the CSFs: EAM top management commitment, EAM awareness and EAM understanding. Our findings also suggest that organisational and technical complexities are severe obstacles to digital transformation in public sector organisations. These problems again lead to challenges in building the organisations' EA service capabilities. The CSFs described in the literature are often deduced from a mix of private and public sector enterprises. It is therefore important to verify that the CSFs also apply to EA implementation in the public sector. Second, the results of our study in a developed country are similar to the findings in the public sector in developing countries (Bakar and Selamat, 2016; Dang and Pekkola, 2016; Banaeianjahromi, 2018b). The third contribution is the suggestion that EA initiatives may progress through the phases of optimism, resistance, decline and finally, reconsolidation for the most persistent ones. The final contribution comprises the four lessons learned that can be useful in planning and implementing an EA initiative.

The implications for practice are that organisations must raise their competency level at the top management, and boards should have the hiring authority of executive level. The different ministries should also be involved in training managers, and the units need to educate a larger number of their employees and develop in-house EA skills and knowledge. We argue in particular that the need for organisational changes related to EA is under-communicated.

\section{References}

Ajer, A.K. and Olsen, D.H., 2018. Enterprise Architecture Challenges: A Case Study of three Norwegian Public Sectors. In: 26th European Conference on Information Systems. Portsmouth, UK, 26 - 28 June. aisel.aisnet.org.

Aier, S., Gleichauf, B. and Winter, R., 2011. Understanding enterprise architecture management design-an empirical analysis. In: 10th International Conference on Wirtschaftsinformatik. Zurich, Switzerland, 16-18 Feb. 2011. alexandria.unisg.ch.

AlSoufi, A., 2014. Bahrain National Enterprise Architecture Framework: a Platform towards a GCC EA Initiative. GSTF Journal on Computing, 2(1), pp.73-80.

Armour, F.J., Kaisler, S.H. and Liu, S.Y., 1999. A big-picture look at enterprise architectures. IT professional, 1(1), pp.35-42.

Bakar, N.A.A. and Selamat, H., 2016. Investigating Enterprise Architecture implementation in public sector organisation: A case study of Ministry of Health Malaysia. In: 3rd International Conference on Computer and Information Sciences, Kuala Lumpur, Malaysia, 15-17 Aug. 2016. IEEE.

Banaeianjahromi, N., 2018a. The Role of Top Management Commitment in Enterprise Architecture Development in Governmental Organizations. Complex Systems Informatics and Modeling Quarterly, 17, pp.95-113.

Banaeianjahromi, N., 2018b. Where enterprise architecture development fails. In: 12th International Conference on Research Challenges in Information Science, Nantes, France, 29-31 May. IEEE.

Banaeianjahromi, N. and Hekkala, R., 2019. Factors Influencing Communication and Collaboration in Enterprise Architecture Development. In: 52nd Hawaii International Conference on System Sciences, HI, USA, 8-11 Jan. 2019.

Banaeianjahromi, N. and Smolander, K., 2016. Understanding Obstacles in Enterprise Architecture Development. In: 24th European Conference on Information Systems. Istanbul, Turkey, 12-15 June 2016. AISeL.

Bernard, S.A., 2012. An introduction to enterprise architecture. 3rd ed. Bloomington IN, United States: AuthorHouse.

Bernus, P., Goranson, T., Gøtze, J., Jensen-Waud, A., Kandjani, H., Molina, A., Noran, O., Rabelo, R.J., Romero, D., Saha, P. and Turner, P., 2016. Enterprise engineering and management at the crossroads. Computers in industry, 79, pp.87102.

Boh, W.F. and Yellin, D., 2006. Using enterprise architecture standards in managing information technology. Journal of Management Information Systems, 23(3), pp.163-207. 
Buckl, S., Ernst, E.M., Lankes, J., Matthes, F. and Schweda, C.M., 2009. State of the art in enterprise architecture management. München: Technische Universität München.

Bui, Q., 2015. Increasing the Relevance of Enterprise Architecture through "Crisitunities" in US State Governments. MIS Quarterly Executive, 14(4), pp.169-79.

Bygstad, B., 2017. Generative innovation: a comparison of lightweight and heavyweight IT. Journal Of Information Technology, 32(2), pp.180-93.

Carota, S., Corradini, F. and Re, B., 2010. The role of applicative cooperation in the Marche Region Enterprise Architecture. In: eChallenges e2010. Warsaw, Poland, 27 - 29 Oct. 2010. IEEE.

Chakravarti, B. and Varma, V., 2008. An enterprise architecture framework for building service oriented e-governance portal. In: IEEE Region 10 Conference. University of Hyderabad, Hyderabad, India, 19-21 Nov. 2008. IEEE.

Currie, W.L. and Guah, M.W., 2007. Conflicting institutional logics: A national programme for IT in the organisational field of healthcare. Journal Of Information Technology, 22(3), pp.235-47.

Dale, M. and Scheepers, H., 2019. Enterprise architecture implementation as interpersonal connection: Building support and commitment. Information Systems Journal.

Dang, D.D. and Pekkola, S., 2016. Root Causes of Enterprise Architecture Problems in the Public Sector. In: 20th Pacific Asian Conference on Information Systems. Chiayi, Taiwan, 27 June-1 July 2016. AISeL.

Dang, D.D. and Pekkola, S., 2017. Systematic Literature Review on Enterprise Architecture in the Public Sector. The Electronic Journal of e-Government, 15(2), pp.132-54.

Denert-Stiftungslehrstuhl, E., 2015. IT Architecture Standardization Survey, . München: Technische Universität München.

Difi, 2012. Overordnede IT arkitekturprinsipper for offentlig sektor. [pdf] Agency for Public Management and eGovernment Available at: <http://www.difi.no/sites/difino/files/arkitekturprinsipper-2.1.pdf> [Accessed 28 May 2015].

Difi, 2017. Årsrapport 2016. [online]. Available at: <https://www.difi.no/sites/difino/files/arsrapport_difi_2016.pdf> [Accessed 24 Oct. 2017].

Drews, P. and Schirmer, I., 2014. From enterprise architecture to business ecosystem architecture. In: 18th International Enterprise Distributed Object Computing Conference Workshops and Demonstrations, Ulm University, Germany, 1-5 Sept. 2014.

Fallmyr, T. and Bygstad, B., 2014. Enterprise Architecture Practice and Organizational Agility: An Exploratory Study. In: 47th Hawaii International Conference on System Sciences. HI, USA, 6-9 Jan. 2014. IEEE.

Flak, L.S., Nielsen, P.A. and Henriksen, J.H.R. 2012. Gevinstrealisering i e-forvaltningsprosjekter. God teknologiledelse i praksis. In: LS Flak (ed.), Gevinstrealisering og offentlige IKT-investeringer, Universitetsforlaget, Oslo, Norway, pp. 1836.

Fountain, J.E., 2004. Building the virtual state: Information technology and institutional change. Brookings Institution Press.

Gong, Y. and Janssen, M., 2019. The value of and myths about enterprise architecture. International Journal of Information Management, 46, pp.1-9.

Hjort-Madsen, K., 2006. Enterprise architecture implementation and management: A case study on interoperability. In: 39th Annual Hawaii International Conference on System Sciences. Kauai, HI.

Hjort-Madsen, K. and Burkard, J., 2006. When enterprise architecture meets government: An institutional case study analysis. Journal of Enterprise Architecture, 2(1), pp.11-25.

Hjort-Madsen, K. and Pries-Heje, J., 2009. Enterprise architecture in government: Fad or future? In: 42nd Annual Hawaii International Conference on System Sciences. Waikoloa, HI, USA, 5-8 Jan. 2009. IEEE.

Hosiaisluoma, E., Penttinen, K., Mustonen, J. and Heikkilä, J., 2018. Lean Enterprise Architecture Method for Value Chain Based Development in Public Sector. In: 18th European Conference on Digital Government, Santiago de Compostela, Spain, 25-26 Oct. 2018.

Janssen, M. and Hjort-Madsen, K., 2007. Analyzing enterprise architecture in national governments: The cases of Denmark and the Netherlands. In: 40th Hawaii International Conference on System Sciences Hawaii, USA, 3-6 Jan. 2007. IEEE.

Janssen, M. and Kuk, G., 2006. A complex adaptive system perspective of enterprise architecture in electronic government. In: 39th Annual Hawaii International Conference on System Sciences. Kauai, HI, USA, 4-7 Jan. 2006.

Jonkers, H., Lankhorst, M.M., ter Doest, H.W., Arbab, F., Bosma, H. and Wieringa, R.J., 2006. Enterprise architecture: Management tool and blueprint for the organisation. Information Systems Frontiers, 8(2), pp.63-6.

Jusuf, M.B. and Kurnia, S., 2017. Understanding the Benefits and Success Factors of Enterprise Architecture. In: 50th Hawaii International Conference on System Sciences. HI, USA, 4-7 Jan. 2017.

Kaushik, A. and Raman, A., 2015. The new data-driven enterprise architecture for e-healthcare: Lessons from the indian public sector. Government Information Quarterly, 32(1), pp.63-74.

Klein, H.K. and Myers, M.D., 1999. A set of principles for conducting and evaluating interpretive field studies in information systems. MIS Quarterly, pp.67-93.

Kotusev, S., Singh, M. and Storey, I., 2015. Consolidating enterprise architecture management research. In: 48th Hawaii International Conference on System Sciences, HI, USA, 5-8 Jan. 2019. IEEE.

Królikowska, B., 2011. Selected Problems of Enterprise Architecture in Public Administration. Studies \& Proceedings Polish Association for Knowledge Management, 42, pp.89-98.

Lange, M., Mendling, J. and Recker, J., 2016. An empirical analysis of the factors and measures of Enterprise Architecture Management success. European Journal of Information Systems, 25(5), pp.411-31.

Lee, S., Oh, S.W. and Nam, K., 2016. Transformational and Transactional Factors for the Successful Implementation of Enterprise Architecture in Public Sector. Sustainability, 8(5), p.456. 
Lucke, C., Krell, S. and Lechner, U., 2010. Critical issues in enterprise architecting-a literature review. In: Americas Conference on Information Systems. Lima, Peru, 12-15 Aug. 2010. AISeL.

Löhe, J. and Legner, C., 2014. Overcoming implementation challenges in enterprise architecture management: a design theory for architecture-driven IT Management (ADRIMA). Information Systems and e-Business Management, 12(1), pp.101-37.

Martin, A., 2012. Enterprise IT Architecture in Large Federated Organizations: The Art of the Possible. Information Systems Management, 29(2), pp.137-47.

Mezzanotte, D.M. and Dehlinger, J., Developing and building a quality management system based on stakeholder behavior for enterprise architecture. In: Software Engineering, Artificial Intelligence, Networking and Parallel/Distributed Computing, 2014 15th IEEE/ACIS International Conference on. IEEE.

Miles, M.B., Huberman, A.M. and Saldaña, J., 2014. Qualitative data analysis: A methods sourcebook. 3rd ed. Thousand Oaks, California, USA: Sage Publications.

Ministry-of-Finance, 2016. Annual budget for 2017. [pdf]. Available at: <https://www.statsbudsjettet.no/upload/Statsbudsjett_2017/dokumenter/pdf/stm.pdf> [Accessed 24 Oct. 2017].

Ministry-of-Health-and-Care-Services, 2009. Samhandlingsreformen: Rett behandling - på rett sted - til rett tid. [pdf] regjeringen.no. Available at:

<https://www.regjeringen.no/contentassets/d4f0e16ad32e4bbd8d8ab5c21445a5dc/no/pdfs/stm200820090047000 dddpdfs.pdf> [Accessed 03 June 2015].

Ministry-of-Local-Government-and-Modernisation, 2009. St.meld. nr. 19 - Ei forvaltning for demokrati og fellesskap. [pdf] regjeringen.no. Available at:

<https://www.regjeringen.no/contentassets/307c7a3832184bbba25b75f4b6c5a40e/no/pdfs/stm200820090019000 dddpdfs.pdf $>$ [Accessed 29 May 2015].

Ministry-of-Local-Government-and-Modernisation, 2011. Digitaliseringsrundskrivet. [online]. Available at: <https://www.regjeringen.no/no/dokumenter/digitaliseringsrundskrivet/id2569983/> [Accessed 10 April 2017].

Moreno, L.M.M., Páez, J.O.T., Parra, A. and Campos, D., 2014. The Colombian Government Enterprise Architecture Framework. In: 1st International Conference on Electronic Governance and Open Society: Challenges in Eurasia. St. Petersburg, Russian Federation, 18-20 Nov. 2014. ACM.

NAV, 2016. Virksomhetsarkitektur i NAV. [pdf] Norwegian Labour and Welfare Administration. Available at: <https://www.difi.no/sites/difino/files/virksomhetsarkitektur_i_nav_v100.pdf> [Accessed 06 June 2017].

$\mathrm{NICT}$, 2008. Tjenesteorientert arkitektur i spesialisthelsetjenesten. [pdf] National ICT. Available at: <https://nasjonalikt.no/Documents/Prosjekter/Avsluttede\%20prosjekter/Tiltak\%2012\%20Tjenesteorientert\%20arkit ektur\%20sluttrapport.pdf> [Accessed 4 Oct. 2016].

Niemi, E. and Pekkola, S., 2013. Enterprise architecture quality attributes: A case study. In: 46th Hawaii International Conference on System Sciences, 7-10 Jan. 2013. IEEE.

Nikpay, F., Selamat, H., Rouhani, B.D. and Nikfard, P., 2013. A Review of Critical Success Factors of Enterprise Architecture Implementation. In: International Conference on Informatics and Creative Multimedia. Kuala Lumpur, Malaysia, 4-6 Sept. 2013. IEEE.

Oates, B.J., 2006. Researching information systems and computing. London: Sage Publications.

OECD, 2017. Digital Government Review of Norway, OECD Publishing.

Ojo, A., Janowski, T. and Estevez, E., 2012. Improving Government Enterprise Architecture Practice-Maturity Factor Analysis. In: 45th Hawaii International Conference on System Science. Hawaii, USA, 4-7 Jan. 2012. IEEE.

Rahimi, F., Gøtze, J. and Møller, C., 2017. Enterprise architecture management: Toward a taxonomy of applications. Communications of the Association for Information Systems, 40(1), p.7.

Regjeringen.no, 2005. Plattform for regjeringssamarbeidet mellom Arbeiderpartiet, Sosialistisk Venstreparti og Senterpartiet 2005-09. [pdf] regjeringen.no. Available at:

<https://www.regjeringen.no/globalassets/upload/smk/vedlegg/2005/regjeringsplatform_soriamoria.pdf> [Accessed 24 Oct. 2017].

Rolland, K.H., Ghinea, G. and Grønli, T.M., 2015. Ambidextrous enterprise architecting: Betting on the future and hacking path-dependencies. In: 23rd European Conference on Information Systems. Münster, Germany, 26-29 May, 2015. AISeL.

Ross, J.W., Weill, P. and Robertson, D., 2006. Enterprise architecture as strategy: Creating a foundation for business execution. Boston, MA, United States: Harvard Business Review Press.

Rouhani, B.D., Ahmad, R.B., Nikpay, F. and Mohamaddoust, R., 2019. Critical Success Factor Model for Enterprise Architecture Implementation. Malaysian Journal of Computer Science, 32(2), pp.133-48.

Saarelainen, M.-M. and Hotti, V., 2011. Does enterprise architecture form the ground for group decisions in egovernment programme? In: 15th IEEE International Enterprise Distributed Object Computing Conference Workshops. Helsinki, Finland, 29 Aug. - 2 Sept. 2011. IEEE.

Schilling, R.D., Haki, K. and Aier, S., 2018. Dynamics of Control Mechanisms in Enterprise Architecture Management: A Sensemaking Perspective. In: 39th International Conference on Information Systems. San Francisco, USA, 13-16 Dec. 2018. AISeL.

Schmidt, C. and Buxmann, P., 2011. Outcomes and success factors of enterprise IT architecture management: empirical insight from the international financial services industry. European Journal of Information Systems, 20(2), pp.168-85. 
Schöenherr, M., Towards a common terminology in the discipline of enterprise architecture. In: International Conference on Service-Oriented Computing. Springer.

Seppänen, V., Heikkilä, J. and Liimatainen, K., 2009. Key issues in EA-implementation: case study of two Finnish government agencies. In: Conference on Commerce and Enterprise Computing. Vienna, Austria, 20-23 July 2009. IEEE.

Seppänen, V., Penttinen, K. and Pulkkinen, M., 2018. Key Issues in Enterprise Architecture Adoption in the Public Sector. Electronic Journal of e-Government, 16(1), pp.46-58.

Shanks, G., Gloet, M., Someh, I.A., Frampton, K. and Tamm, T., 2018. Achieving benefits with enterprise architecture. The Journal of Strategic Information Systems, 27(2), pp.139-56.

Simon, D., Fischbach, K. and Schoder, D., 2013. An exploration of enterprise architecture research. Communications of the Association for Information Systems, 32, pp.1-72.

Ulriksen, G.-H., Pedersen, R. and Ellingsen, G., 2017. Infrastructuring in healthcare through the openEHR architecture. Computer Supported Cooperative Work, 26(1-2), pp.33-69.

Valtonen, K., Mäntynen, S., Leppänen, M. and Pulkkinen, M., 2011. Enterprise Architecture Descriptions for Enhancing Local Government Transformation and Coherency Management: Case Study. In: 15th IEEE International Enterprise Distributed Object Computing Conference Workshops. Helsinki, Finland, 29 Aug. - 2 Sept. 2011. IEEE.

Van Der Raadt, B., Schouten, S. and Van Vliet, H., Stakeholder perception of enterprise architecture. In: European Conference on Software Architecture. Springer.

Venkatesh, V., Bala, H., Venkatraman, S. and Bates, J., 2007. Enterprise Architecture Maturity: the Story of the Veterans Health Administration. MIS Quarterly Executive, 6(2), pp.79-90.

Walsham, G., 1995. Interpretive case studies in IS research: nature and method. European Journal of Information Systems, 4(2), pp.74-81.

Weiß, K.S., 2015. Institutionalizing Architectural Coordination in Organizations. University of St. Gallen.

Winter, R. and Schelp, J., 2008. Enterprise architecture governance: the need for a business-to-IT approach. In: ACM Symposium on Applied Computing. Fortaleza, Ceara, Brazil, March 16-20 Mar. 2008. ACM.

Zachman, J.A., 1987. A framework for information systems architecture. IBM systems journal, 26(3), pp.276-92.

Zadeh, M.E., Lewis, E., Millar, G., Yang, Y. and Thorne, C., 2014. The use of viable system model to develop guidelines for generating enterprise architecture principles. In: IEEE International Conference on Systems, Man and Cybernetics. San Diego, California, USA, 5-8 Oct. 2014. IEEE.

$\varnothing v$ relid, E., Bygstad, B. and Hanseth, O., 2017. Discursive formations and shifting strategies in eHealth programmes. In: 25th European Conference on Information Systems. Guimarães, Portugal, 5-10 June 2017. 